\title{
Contribution of NGOs for Socio-Economic Development in Bangladesh
}

\author{
Ishita Roy ${ }^{1}$, Tanzil Al Raquib², Amit Kumar Sarker ${ }^{1, *}$ \\ ${ }^{1}$ Department of Management Studies, Bangabandhu Sheikh Mujibur Rahman Science \& Technology University, Gopalganj, Bangladesh \\ ${ }^{2}$ Department of BBA, University of Development Alternative, Dhaka, Bangladesh
}

Email address:

ishita_ipu@yahoo.com (I. Roy), tanzilsina@yahoo.com (T. A. Raquib), amit_bsmrstu@yahoo.com (A. K. Sarker)

${ }^{*}$ Corresponding author

\section{To cite this article:}

Ishita Roy, Tanzil Al Raquib, Amit Kumar Sarker. Contribution of NGOs for Socio-Economic Development in Bangladesh. Science Journal of Business and Management. Vol. 5, No. 1, 2017, pp. 1-8. doi: 10.11648/j.sjbm.20170501.11

Received: October 19, 2016; Accepted: November 28, 2016; Published: January 12, 2017

\begin{abstract}
Nowadays Non-Governmental Organizations or NGOs have become an extensively discussed theme in the third world countries as well vastly in social business world. Bangladesh is no exception. The NGOs have appeared as the savior of countless number of people without food, cloth, education and basic health facilities. Bangladesh is one of the top thirteen underprivileged countries. With the record of being the most densely populated country on earth and feeble manpower competency, Bangladesh is facing massive challenge to meet up the demand of her ever- increasing population. Hence NGOs in Bangladesh can continue playing the role of catalyst in the attainment of sustainable economic growth and development provided, an endurable, warm and dependable relationship is there between the Government and NGOs where both are working for the benefit of the people with numerable activities. Their main tasks are to organize these people, create awareness in them and make them development oriented. These organizations are working based on the assessed need and demand of the grass root level farmers and women. By involving the beneficiaries directly, they are working within the context of overall national planning for development.
\end{abstract}

Keywords: Poverty, Rural Areas, Activities, Development, NGOs \& Analysis

\section{Introduction}

Non-governmental Organizations (NGOs) play an important role in the economic development of developing countries. They provide services to society through welfare works for community development, assistance in national disasters, sustainable system development, and popular movements. They take numerable for actions developing our society. With the record of being the most densely populated country on earth and feeble manpower competency, Bangladesh is facing massive challenge to meet up the demand of her ever-increasing population. Although agriculture sector is the main source of income for this ruralagro based country, unfortunately this sector has completely failed to create rewarding employment opportunity for the landless. Considering these overall situations, the NGOs are working on poverty eradication by directly involving the poverty stricken population. Their target groups are basically the poor and vulnerable ones with hardly any possessions. Their main tasks are to organize these people, create awareness in them and make them development oriented. These organizations are working based on the assessed need and demand of the grass root level farmers and women. By involving the beneficiaries directly, they are working within the context of overall national planning for development.

Through in short overview we turn a consequence, that the NGOs are attracting increased attention and recognition among academics and practitioners of development and development assistance. Many researchers support NGOs' activities because of their proximity to remote communities and to the poor their efficiency and low cost of operations e.g., micro-credit programs (Mask, 1995; Hulme \& Moseley, 1996; USAID, 1996), their promotion of sustainable system development (Korten, 1990; Smillie, 1995), and their 
potential role for organizing and representative bodies in civil societies (Brown and Korten, 1991; Carroll, 1992). The rapid growth of NGOs is also seen as a consequence of governments' failure to alleviate poverty, growing levels of bureaucracy and corruption and a lack of accountability of government (Booth, 1994; Fisher, 1998; Nelson, 1995; Clarke, 1998, Lewis, 2001).

\section{Literature Review}

Not only is the alleviation of rural poverty but also NGO plays numerable activities to develop territory wise the ultimate social development it's often referred as the unavailability of resources for meeting the basic living standard (Nilsson, 2012). We know that the rural poverty can be measured on the basis of rural households' dependency on resources like land or labour, market accessibility and the protection by society (Douarin, et. al., 2011). The existence of poverty across the world has been evidenced at least for centuries and the underpinning of poverty situation at the rural level has been remaining as the key feature from the later part of the nineteenth century (Smith and Lüsted, 2010). From the individual viewpoint, poverty is often considered as attached with the income capacity of the population (Chambers, et. al., 2011). However the trends and features of poverty are not the same in all over the world and in all geographical locations. For example, the poverty in Africa is often considered as the outcome of drought or famine, where in Asia mainly due to political or bureaucratic corruption and in Europe or America due to the economic slowdown or losses of jobs (Olsen, 2010). Major poverty alleviation initiatives started to direct towards the well-being of the poor people through the involvement of the government (Ruben, et. al., 2007). Rural poverty cannot be a persistent issue and governments all over have been playing the pivotal role is initiating and implementing the development programmes those have been designed for the wellbeing of poor rural populations (Glauben, et. al., 2012). However, the major lack of a developed communication system, weaker administrative set up and the distribution of information have been acting as main obstacles for full pledged poverty alleviation programmes that can be beneficial for the overall development of the country's rural poverty status (Dorward, et. al., 2004). Some of the banks provides microcredit to the poor without any collateral to generate employment, income and self-esteem. The process that takes places in the Grameen Bank is better characterized as organizational development for people's direct participation in economic activities. Other hand have some banks also played this kind of roles. Based on those issues the majors areas in which Bangladeshi NGOs are presently involved include relief and rehabilitation; rural development; education; health and family planning; micro-credit; infrastructure development; employment generation; development programmes sustainable development; and research and communication (Begum, 2003). It is estimated that there are innumerable NGOs working in Bangladesh (Huq, 1997)

\section{Research Methods}

Following the typologies of research methodologies, this is often believed that the qualitative method is considered as traditional and this has been considered as having validity (Hair, et. al., 2011). Often regarded that the qualitative method is relatively well fit for studies that are based on human ideas with their activities and those tend to understand the existing psycho-sociological issues (Bryman and Bell, 2011). This study has aims to attach the effects of some selected development project of a non-governmental organization with special concentration on poverty alleviation and employment generation. This represents the relevancy of qualitative research method for this study as the most suitable. In order to understand the in-depth human viewpoints, the case study method has been found effective. This is often argued that the information and data that are usually extracted from the practical field often need to employ case study method. This can be considered as the most efficient way to perform such activities than general survey or experimental method (Gerring, 2004). In the explanatory case study, the research questions are capable of meeting the elementary research aspects (Ghauri and Grønhaug, 2010). The research that progresses through interviews tends to have more in-depth information than the other types (Blumberg, 2008). Thus this study has been based on qualitative research with the explanatory type of case study and followed by in-depth qualitative interviews. The attached numerical data represents part of the qualitative method. Some key criteria for case study villages' selection were considered: the Grameen Bank (GB), BRAC \& others programmes intervened villages, the accessibility of the researchers and the programme integrity with the beneficiaries. This study used both the qualitative and quantitative method of research. The findings collection were conducted face-to-face of information provider and between the timeframe of the middle of May to the middle of June, 2016. In total 17 informer were conducted in three different categories. Out of these interviews, 15 were conducted with the direct and indirect beneficiaries in the case study villages. These interviewees were divided into two broad areas of poverty alleviation and employment generation and their number were 8 each. The rest 2 were conducted with officials of GB \& BRAC (Selected). The beneficiaries were asked about the activities or programmes undertaken by GB, BRAC $\&$ others and the extent of benefits they were getting. They were also asked about the direct and indirect benefits from their contribution through activities, while, the Key Informants were asked about the official viewpoints

\section{Profile \& Activities of Two Broad Ngos in Bangladesh}

\subsection{Grameen Bank}

Among the micro-finance organizations (NGO's) in Bangladesh, Grameen bank is in a leading position who is 
trying to develop poor as well as venerable people providing micro-loans without requiring any collateral or mortgage. Its aim is to create a poverty museum each and every area in Bangladesh. However presently Grameen replication is administered all over the world and dedicated to create poverty free world. With this initiation, this paper focuses how micro-finance is helping out to eradicate poverty in Bangladesh. Following this approach, this paper has structured into some parts. Here, discusses about microcredit system, difference between Grameen Bank and Conventional Bank. Next part highlights the structure of micro-credit, institutional framework and advancement of the microfinance institution. Part three illustrates grameen loan system, investment procedure and replica model elucidated. Fourth part describes causes of poverty and its reduction strategy framework. The implications towards eradication of poverty explained in part fifth and finally, social and economic impact of micro-credit in Bangladesh has been conferred. All those parts are crucially related with the socio-economic development of Bangladesh with some situation wise corrective activities.

View point of Bangladesh Micro-credit is a small amount of loan given to the poor to develop their standard of living. This small amount of loan can help people to come out the cycle of poverty by generating income. Defining microcredit, it is a - "Financial service where small amounts of money (usually around $\$ 50 \$ 150$ ) are loaned to poor people for use as a capital to start or expand small businesses" [2]. It is amazing how does the little amount of money gives strength to the poor to start a business and helping to break out the vicious cycle of poverty. This small amount of loan or financial supports to the needy people helps to encourage setting up free-businesses. In other way, it is a financial innovation system that comes from grameen banking system or procedure which is based on trust and collateral-free and opposite to conventional banking system. In order to get loan people go to the conventional bank but Grameen Bank approaches rootless or landless people's door steps. It is incredible that, without guarantee any bank can allocate or sanction loan to the rootless or vulnerable people. This loan giving approach placed Grameen Bank in a unique position in micro-finance and approaches beyond the boundaries. Different activities plays this NGO these are as below.

(1) Application of Microcredit: Grameen Bank is founded on the principle that loans are better than charity to interrupt poverty: they offer people the opportunity to take initiatives in business or agriculture, which provide earnings and enable them to pay off the debt.

Since 1995, Grameen has funded 90 percent of its loans with interest income and deposits collected, aligning the interests of its new borrowers and depositor-shareholders. Grameen converts deposits made in villages into loans for the more needy in the villages (Yunus and Jolis 1998).

It targets the poorest of the poor, with a particular emphasis on women, who receive 95 percent of the bank's loans. Women traditionally had less access to financial alternatives of ordinary credit lines and incomes. They were seen to have an inequitable share of power in household decision making. Yunus and others have found that lending to women generates considerable secondary effects, including empowerment of a marginalized segment of society (Yunus and Jolis 1998), who share betterment of income with their children, unlike many men. Yunus claims that in 2004, women still have difficulty getting loans; they comprise less than 1 percent of borrowers from commercial banks (Yunus 2004). The interest rates charged by microfinance institutes including Grameen Bank is high compared to that of traditional banks; Grameen's interest (reducing balance basis) on its main credit product is about $20 \%$. They have played strong role in rural development through micro finance activities.

(2) Grameen Bank continues to enlarge its outreach: Grameen Bank continued its onward march to reach new milestones in terms of the number of its members and the area it covers. 96,248 new members joined the Grameen family in the year of 2014 bringing the total enrolment to 8.64 million. More than half of the countries of the world have a population smaller than the number of GB members. With 40 zonal, 266 area and 2568 branch level offices, Banks network now encompasses 81,390 over $93.16 \%$ of the country's nearly 87,362 villages spread across length and breadth of the country. Now in 2016 it's have increased number of zonal, area, branch level offices and its network that flows across breadth of country.

(3) Grameen Loan System, Investment \& Replica: Grameen bank adopted unique loan systems that are voluntary formation where people create groups through it each and every group is consisting of five in numbers. Only two members are allowed to take a loan at first time. If the performances are reaching at the satisfactory level then next two borrowers can apply for loans. Finally, fifth member can be selected for loan. After approving loan Grameen Bank arranges a training program. Training program comes after the loan is because Grameen Bank assumes that if it starts first most of the borrower will be scared with the system and they will lose their interest to get loans.

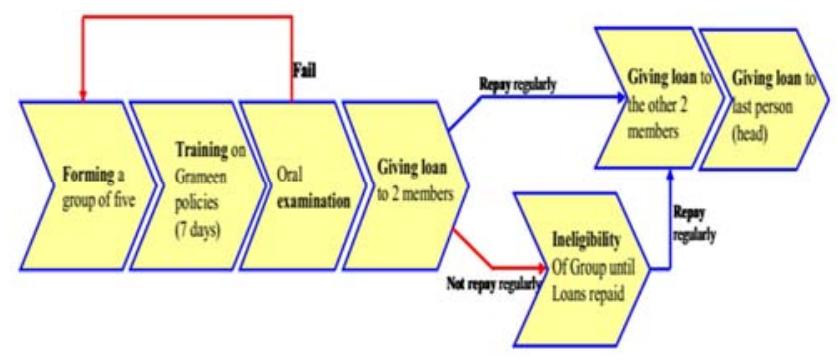

Figure 1. Loan Distribution System.

(4) Created Hope for the Poor: More and more women are being engaged in small-scale business in Bangladesh and other parts of the world. This is largely due to the poverty issue and traditional roles attached to them which limit their opportunities for employment in job 
markets. A large number of women are at a disadvantage in formal sector employment due to their exclusion from education and skills training, traditional concepts of sexual division of labor, and the incompatibility of wage employment with household responsibilities. Traditionally, in Bangladesh, men owned and controlled agricultural land in the rural areas.

Beside the Grameen Bank many NGOs also have been providing microcredit, education, skill training, awareness and capacity building programme and motivating them for greater participation in social development and income generation activities to improve their overall socioeconomic condition

(5) Service at the Door Steps of the poor: Instead of the poor coming to the bank Grameen Bank carries its services to the comfort zones of their door steps. It explains why the Bank's members consist largely of women who normally shy away from the glare of a conventional banks with branches located away from where the poor live. All banking transactions except loan disbursements are done in the meetings of the borrowers at the village level centres organized by the Bank's centre manager. New branches are required to fund themselves entirely with the deposits they mobilize. No fund from head office or any other office is lent to them. A new branch is expected to break even in the first year of its operation.

(6) Interest Rates are based on repayment capacity: The interest rates of the Bank are structured with an eye on the financial status and repayment capacity of the borrowers. It does not subscribe to the conventional wisdom of loading the cost of funds for calculating interest rates for lending to the ultra-poor. On the basis of this principle the interest rates on loans for the 4 categories of Grameen Bank borrowers are as follows:

Table 1. Loan basis interest rates.

\begin{tabular}{ll}
\hline Loan Category & Interest Rate per annum \\
\hline Loans for Income Generating Activities (IGA) & $20 \%$ \\
Housing Loans & $8 \%$ \\
Higher Education Loans & \\
i. During the study period of about 3 - 5 years & $0 \%$ \\
ii. After the study period & $5 \%$ \\
Struggling Members (beggars) Loans & $0 \%$ \\
\hline
\end{tabular}

(7) The Grameen Generalized System: This kind of NGO and its system was introduced in 2000 to overcome the financial constraints of the borrowers to tide over the bad days that seriously impair their capacity to repay their bank loans. The system is simple and customer friendly that provides a leeway to the member to remain in the Bank's mainstream rather than opting out of Bank. The Grameen has four important windows for lending money--basic loan, housing loan, higher education loan and struggling members (beggars) loan programme

(8) Housing for the poor: A shelter over the head, food and clothing are the three most important needs of the mankind. Realizing the importance the shelter, GB introduced housing loan programme in 1984 to enable its borrowers to build a modest shelter over their heads. The ownership of a house infuses people with a sense of pride, security and self-respect that, in turn, provides a stepping stone to achieve economic prosperity and improved social status. The ceiling for a housing loan is BDT 25,000 for construction of a simple tin-roof house. The average size of the loan is BDT 13,063 (USD 169) per borrower. The interest rate is 8 percent per annum, repayable over a period of five years. During 2014, housing loans amounting to BDT 22.80 million (USD 0.29 million) were provided to build 1,391 houses. It brings the total number of houses built with the housing loans to 696,789 since inception.

(9) Scholarships for the children of Grameen members: Grameen Bank offers scholarships to the children of Grameen members to ease their financial constraints for payment of school dues, purchase of books and stationery. At least $50 \%$ of the scholarship money must go to the girls and the remaining 50\% to both boys and girls based on overall performance. About 25,500 children, at various levels of school education, were awarded the scholarships during the year under review. It brings the aggregate number students since the inception of the programme to 241,035 up to December, 2014, involving an amount of BDT 399.29 million (USD 5.15 million)

(10)Higher Education Loans: Grameen Bank did not want to leave children of the members at the lurch after finishing the school level study. So it introduced the Higher Education Loan programme in 1997 to open opportunities for talented children of its borrowers to pursue higher education in medicine, engineering, agriculture and other higher education programmes at the graduate (with honours) and postgraduate levels. The loans are intended to cover all expenses incurred by the students from the beginning to the end of the study period. The loans cover admission fees, course fees, cost of stationery, food and accommodation and other related expenses. By the end of the year under review 53,175 students pursuing courses in disciplines were provided loans under this programme.

(11)Nursing Education loans for the female children of Grameen Bank borrowers: To assist the children of Grameen Bank borrowers to secure jobs at home and abroad it lends money for study in a 3-year Diploma in Nursing and Midwifery in the international standard Grameen Caledonian College of Nursing. 224 students have enrolled for this course. 127 students have already successfully completed the course. Of them 71 have secured jobs in different hospitals and clinics, 4 have gone for higher training in Glasgow Caledonian University, Scotland while 10 students have enrolled in B. Sc. level courses in nursing in Bangladesh.

(12)Village Phones: Grameen Bank provided loans to 
$1,428,902$ borrowers up to 2014 to buy mobile phones and offer telecommunication services in nearly half of the villages of Bangladesh. It is also generating revenue for GrameenPhone, the largest telephone company in the country. Village phones use 2.22 per cent of the air-time of the company, while their number is only 1.89 per cent of the total of telephone subscribers of the company.

(13)Success of Members in Election of Local Bodies: Grameen system provides a flavour of election process to the borrowers of the Bank. They routinely go through electing group chairman, secretaries, centrechiefs and deputy centre-chiefs every year. They elect board members for running Grameen Bank every three years. This experience provides them a launching pad to run for public offices with a fair degree of success. In 2003 local government (Union Porishad) election 7,442 Grameen members contested for the reserve seats for women. Of the 3,059 members came out successful.

(14) Others activities:

Table 2. Others activities.

\begin{tabular}{ll}
\hline Loan Insurance & Balance of deposits under loan insurance programme stood at BDT 8,764.91 million (USD 113.08 million) as on December 31, 2014 \\
Life Insurance & $\begin{array}{l}\text { Each year families of deceased borrowers of Grameen Bank are paid amounts ranging from BDT 14 to 16 million (USD 0.17 to 0.21 } \\
\text { million) as life insurance benefits. Each family receives BDT 1,500 which the deceased was a Grameen Bank borrower. }\end{array}$ \\
$\begin{array}{l}\text { Micro-enterprise } \\
\text { Goans }\end{array}$ & $\begin{array}{l}\text { Grameen Bank has steered many poor to cross over the poverty line. The Bank continues to stand by them to help them reach even } \\
\text { higher echelons of prosperity. The Bank provides larger loans, called micro-enterprise loans, to these fast moving members }\end{array}$ \\
\hline
\end{tabular}

Source: Grameen Bank Annual Report 2014

\subsection{Brac}

BRAC was originally known as the Bangladesh Rehabilitation Assistance Committee. It was created in 1972 by Sir Fazlé Hasan Abed in a small district in Bangladesh.7 It was a small-scale relief and rehabilitation project to help returning war refugees after the Bangladesh Liberation War of 1971. 9 months after BRAC started, 14000 homes and several hundred boats were built and/or rebuilt for relief. This included medical centers and other essential services (like water).

After the initial relief work was finished BRAC turned its attention towards long-term developments as they realized the problem was chronic and structural, so they reorganized themselves changed their name to Bangladesh Rural Advancement Committee. Their new mission started focusing on increasing the quality of life threw poverty, illiteracy, and other problems.

In 1975 a Research and Evaluation Division (RED) was set up to analyze and evaluate its tasks and guidance for its organization to develop, this division also help provide information for researchers and other NGOs which since inception has made 1,398 research reports and 372 journal articles.

BRAC's main priorities include focus on women, grassroots empowerment, health and education, empowering farmers, inclusive financial services and self-sustaining solutions.

Through their education BRAC has enrolled 3 million children, $65 \%$ of whom are girls and help built almost 1000 libraries and 38,000 schools worldwide. In 1999, BRAC started Information Technological Institute and a university 2 years later. This BRAC University was intended to created leaders in their nation and help Bangladesh.12

Another educative goal of BRAC was to reduce child mortality rate in half, mostly focusing on the main culprit diarrhea did this. More than $25 \%$ of all infants died before 5 .
To combat this, BRAC started an Oral Therapy Extension Program (OTEP) in 1979. Working with religious schools and going door-to-door educating mothers BRAC covered more than 14 million households making it the highest use of oral rehydration among all developing countries, now the infant mortality rate is less than $8 \%$. They are able to produce these results from there 97,000 health workers.

For employment, income and credit services in 1974, BRAC started providing microcredit (small amounts of money, low interest, usually to new businesses) and assess the usefulness of credit on the poor. It currently provides $\$ 10$ billion in microloans annually. $90 \%$ of BRACs microloans have gone to women with a $98 \%$ repayment rate. A BRAC bank was started with the intention of helping fund small and medium sized businesses.

BRAC than in 1977, they helped organize village members to develop their own communities through a program called Village Organizations (VO). BRAC also set up a print press and a handcraft retail chain called Aarong (which employs 65,000 artists) and later a Dairy and Food project. They continued to provide enterprise training and now have such programs as: bull station, feed mill and broiler production. Through these projects BRAC is now self-funding $70-80 \%$ of its organization. They have also hired over 100,000 employees with which $70 \%$ are women. They have expanded to 10 other countries and 3 continents. And helped over 120 million people and are rated one of the top NGO's in the world.

Other successes of BRAC can include the large response to Cyclone SIDR that hit Bangladesh in 2007 helping send emergency relief to over 300,000 residents from around 60,000 homes. BRAC also noting the global warming problem in Bangladesh will cause problems started a tree growing program that alone has 15 large tree nurseries.

Though BRAC is not the only NGO who has had strong presence in Bangladesh another called the Grameen Bank. Initially they also started as a microcredit company, but they began to diversify. Some of their notable achievements for 
example have been creating a microcredit system, vast business ventures from knitwear to software, and improved communications infrastructure.

For all this positivity that BRAC does there are also criticisms. One big looming problem that some people criticize is an accomplishment that they promote, BRAC is seen my many Bangladeshi as there second government. Some criticize that they have too much power and that their quest for economic improvement is causing inflation and environmental problems (like desertification, drying up water and increasing arsenic in the drinking water). BRAC in defense said economic improvement comes at a cost.

Today BRAC is referred to as "by most measures the largest, fastest-growing non-governmental organization (NGO) in the world - and one of the most businesslike."

Role Play Sector

(1) Education sector: There are 3 reasons why children are not educated in the countryside of Bangladesh. First of all, families need the help of children on farms so that there is no time for school. Secondly, the feeling of alienation for traditional school system does not allow uneducated parents and their children to become literate. Finally, the third reason is harassment of girls. However, BRAC improved the situation creating non formal Educational Program; it opened schools in rural areas where kids from poor families can get decent high-quality primary education. Teachers who are hired by BRAC are the citizens of the villages who had taken special courses that last for 9 years in order to have appropriate qualification. The program was designed with the help of the mothers from that area and it responded most of the schooling issues: due to shorter school hours and little but efficient homework kids are still able to help families on the farm. Smaller size of classes (30-35 children per class), special care for pupils and engaging teaching styles contributed to the development of educational system.

(2) Social support: Also 300000 Village Organizations were formed, each of them consists of 35 to 50 women from a certain neighborhoods. Almost all of 80000 villages are under the control of BRAC. A huge system of 14 training centers and 2,800 branch offices operates all over the country with a budget of half a billion U. S. dollars. As leaders of BRAC were using funds efficiently, now it is $70 \%$ self-supporting. Now the organization gets profits from the range of productive enterprises that it established. BRAC generates income from small and medium-size enterprises that produce chalk, seeds, shoes and sanitary napkins. This small production creates jobs thereby reducing poverty. The organization provides affordable goods for poor population and advocates them when they are in need of professional help. The organization turned to be extremely big but it is still flexible.

(3) Economic development: BRAC's Economic Development programme includes microcredit. It provides collateral-free credit using a solidarity lending methodology, as well as obligatory savings schemes through its Village Organizations. Reaching nearly 4 million borrowers, Village Organizations provide loans to poverty groups. BRAC has reached out to those who, due to extreme poverty, cannot access microfinance. BRAC defines such people suffering from extreme poverty as the 'ultra-poor', and has designed a programme customized for this group that combines subsidy with enterprise development training, healthcare, social development and asset transfer, eventually pulling the ultra-poor into its mainstream microfinance programme.

(4) Healthcare sector: BRAC took care of education and small part of financial sector as well as healthcare. The new strategy for healthcare included directly observed treatment short course (DOTS) for TB and training for oral rehydration therapy (ORT). The organization is testing every single program until it shows clear results and strong evidence of efficiency.

(5) Disaster relief: BRAC conducted one of the largest NGO responses to Cyclone SIDR which hit vast areas of the south-western coast in Bangladesh in midNovember 2007. BRAC distributed emergency relief materials, including food and clothing, to over 900,000 survivors, provided medical care to over 60,000 victims and secured safe supplies of drinking water. BRAC is now focusing on long-term rehabilitation, which will include agriculture support, infrastructure reconstruction and livelihood regeneration

(6) Organization failures: However, nothing in the world is perfect and BRAC is not an exception. The NGO had its' failures as it is still a "learning organization". Purchase of poorly designed motorcycles from China and an attempt of the production of silk, tube wells and pumps did not succeed but it should be noted that BRAC had nothing to hide, did not blame anyone else for missteps and talked openly about their failures. The $\mathrm{NGO}$ is respected for honesty and the ability to learn from its' mistakes.

The founders of BRAC are about to retire and it is time to replace them but the new generation should have the same skills and talents of managing such a huge organization and be prepared for harsh reality full of challenges.

(7) International success: The influence of BRAC was striking. The innovations in non-formal primary education, health and banking system have been emulated in other countries such as Afghanistan, Sri Lanka, Uganda, southern Sudan, Tanzania, Pakistan, Sierra Leone, and Liberia. BRAC started operating internationally. BRAC continues to innovate with new ventures such as the Targeting the Ultra poor program.

Despite a substantial amount of work BRAC performs, it is growing steadily and is making a huge contribution to the reduction of poverty in different parts of the world.

(8) Significance of NGO and its impact on global development: NGOs have become increasingly more important in promoting sustainable development. 
NGOs often hold a major role in a nation's political, economic or social activities, as well as assessing and addressing problems in both national and international issues, such as human, political and women's rights, economic development, democratization, inoculation and immunization, health care, or the environment. NGOs play a significant role in partnering with international development partners to bring resources to countries that are in need.

However, one characteristic diverse NGOs have is that they are not interested in short-term financial goals. Therefore, they are able to devote themselves to issues which occur across longer time period, such as climate change, malaria prevention or poverty reduction. NGOs often have a high degree of public trust, which makes them a useful but not always sufficient intermediary for the concerns of society.

In the developing world the role of NGOs is crucial. For instance, in Bangladesh BRAC's role has been pivotal in providing food to victims of famine and displacement. Although BRAC deals with a diverse range of issues, its main mission at the moment is poverty reduction. BRAC provides microloans, self-employment opportunities, health services, education, and legal and human rights services. The BRAC model illuminates how comparative advantages of NGOs can function to support poverty reduction and illustrates conditions under which NGOs extend their activities in the face of deficiencies of government and private-sector actors.

NGOs often provide essential services in the developing world that in governmental institutions would provide. As a result of ineffective legal framework or small government capacity, NGOs in Bangladesh broad role in addressing legal and political issues, such as strengthening economic and social programs. They provide services that are in line with current governmental policy, acting as a contributor to economic development, essential services, employment and the budget.

Although NGOs may lack traditional political power, they possess a "moral authority" that cannot easily be disregarded. NGOs have a moral responsibility "to alert the public to the global predicament; to educate its members on the significance of environmental problems for their lives and those of their children; to mobilize opinion in support of environmentally sound policies; to develop new policy ideas; and to act directly in the political arena as in the environment to secure a sustainable future" (Environmental NGOs 1982).

NGO's roles can be divided in three main sectors: service delivery, catalysis and partnership. These roles are usually combined within a particular organization. For example, an NGO may undertake service delivery in order to build trust in a local community, which will create a platform for community organizing or advocacy. One form of catalyst is the NGO that aims to bring a change through advocacy and seeking influence, to innovate and to apply new solutions to development problems.

Other applications: As for other applications and other countries in which BRAC operates, since 2002 BRAC has been using its experience to accelerate poverty alleviation in other countries. It works in a growing number of Asian and African countries, where it can achieve a major impact on reducing poverty and improving lives.

\section{Conclusion}

The poverty and the unemployment situation has prevailed in rural Bangladesh for decades. There has not been any major improvement of the degree and overall situation of this problem leading towards sustainable development. However, the involvement of NGOs like the GB \& BRAC has made initiatives to improve the general situation at least to some extent. The rural Bangladesh scenario in terms of poverty and unemployment has been visibly influenced with the involvement of NGOs like GB \& BRAC. One of the important findings of this study is the current trend of poverty and unemployment, education facility, health \& others situation in rural Bangladesh. The actual barrier dynamics in rural Bangladesh have never been understood in the academic similar pattern in the case study villages. Different types and views have influenced that kinds of barrier situation. The labor power has been mainly thought to be employed in the agricultural sector, while, the service sector comes to the second position. However, the recent trend showed that the majority of labours in the case study sites have been gradually attracting to day labour. Other finding is the peoples' attitude towards the development and employment generating activities by these nongovernmental organization. The natural calamities along with other types of disasters have increased the poverty and unemployment rate and status to some extent. But, such development activities have less acceptability among the rural populations, because, the attitude and experiences have not been pleasant with this selected NGOs Grameen Bank \& BRAC employees. This study has been designed with the basic objective for exploring the contributions those the non-governmental organizations have had in the rural settings of Bangladesh. These the causes of Development rurally through their Social Business steps like; loan, insurance, Housing loan for poor people \& other activities. In addition this study has attempted to understand the degree and volume of ongoing poverty situation along with the unemployment status in Bangladesh. This study has also tried to outline the effects of activities and initiatives undertaken by the non-governmental organizations. Findings have been able to explore the present status of poverty and unemployment situation in rural Bangladesh through the case studies. This has again helped to offer the understanding of the programmes that are carried out and considered as successful in rural Bangladesh. The activities and initiatives carried out by the nongovernmental organizations have been found as both positive and negative in regard to building a better and sustainably developed Bangladesh. This study has faced two basic limitations. First, the limited time allotment that has restricted the researcher from carrying out more interviews that could possibly represent more types of populations. The second limitation 
has been the rural populations' unwillingness to share their views and ideas about Grameen Bank \& BRAC and its activities having a fear that this can have negative impacts on their relationship with GB \& BRAC. However, the researcher has attempted to overcome these limitations and to enrich the study through personal observation. The dynamics and extent of rural poverty traditionally cover vast areas and there is a clear opportunity to conduct further studies on diversified aspects in the future.

\section{References}

[1] Grameen Bank - Annual Report 2014.

[2] http://www.bangladesh-bank.org.

[3] http://www.greenstar.org/microcredit/microcredit-brief.pdf.

[4] http://www.grameen-info.org, 176.

[5] http://www.grameen-info.org, 109.

[6] Mohammad Yunus (2007) Banker to the Poor: Micro-lending and the battle against world poverty, Yew York.

[7] Lovell, C. H. (1992). Breaking the cycle of poverty.

[8] Bangladesh BCC Working Group (2012), Home, [Online] available at: http://bit.ly/10bcwtP (accessed: the 20th February, 2012).

[9] Bangladesh Economy (2012) Bangladesh economy 2011, [Online] available at: http://bit.ly/w5pkn7 (accessed: the 20th February, 2012). Baker, S. (2006), Sustainable development, Routledge, Oxon, UK.
[10] Blumberg, B. (2008), Business research methods, McGrawHill Higher Education, New York, USA.

[11] The Role of NGOs in "The Sustainable Development in Bangladesh" - Hassan A. \& 1, Forhad A. (Present Environment and Sustainable Development, Vol. 7, No. 2, 2013).

[12] Md. Khaled Shukran, Farhana Rahman (2011) A Grameen Bank Concept: Micro-credit and Poverty Alleviation Program in Bangladesh.

[13] Bangladesh BCC Working Group (2012), Home, [Online] available at: http://bit.ly/10bcwtP (accessed: the 3rd March, 2015.

[14] BRAC- Alleviation of Poverty and Empowerment of Poor (2009) Retrieved July 2009 from: http://www.brac.net/index.php?nid=9 (accessed: the 3rd March, 2015).

[15] Document of The World Bank, Poverty Reduction Strategy Paper, Bangladesh, Report no. 34448bd, joint IDA-IMF staff advisory note, December 29, 2005.

[16] Mohammad Yunus (2007) Banker to the Poor: Micro-lending and the battle against world poverty, Yew York. http://www.grameen-info.org, 109 (accessed: the 3rd March, 2015).

[17] Jamadar M. - Role of Grameen Bank Microcredit Programme in Poverty Reduction.

[18] Zohir S. - NGO Sector in Bangladesh An Overview.

[19] Ahsan A. H. M. K. (2005), "Role of NGO's Microcredit Programme in Poverty Reduction in Bangladesh: A Study on some Selected NGOs", Pakistan Journal of Social Sciences 3 (8): 1053-1059. 